\title{
Inhibitory Activities of Surface Associated Bacteria Isolated from the Marine Sponge Pseudoceratina purpurea
}

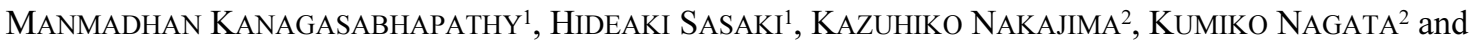 \\ SHINICHI NAGATA ${ }^{1 *}$ \\ ${ }^{1}$ Environmental Biochemistry group, Research Center for Inland Seas, Kobe University, 5-1-1 Fukaeminamicho, \\ Higashinada-ku, Kobe 658-0022, Japan \\ ${ }^{2}$ Department of Bacteriology, Hyogo College of Medicine, 1-1, Mukogawacho, Nishinomiya 663-8131, Japan
}

(Received April 19, 2005-Accepted June 21, 2005)

The effects of four strains of Gram positive bacteria (PS2, PS9, PS11, and PS79) isolated from the sponge Pseudoceratina pupurea on the growth of a set of fouling bacteria and standard strains of genera Vibrio-Photobacterium were examined. Using a paper disc diffusion method, 4 sponge isolates were found to have inhibitory activity against 4 of 12 isolates of the fouling bacteria. All of the four bacterial supernatants also showed inhibitory activity against Vibrio alginolyticus and $V$. fischeri, while sponge extracts inhibited every strain tested. Phylogenetic analysis using 16S rRNA gene sequences revealed that three of the sponge isolates (PS2, PS9 and PS79) belonged to the genus Bacillus and one (PS11) belonged to the genus Virgibacillus. The isolation of strains possessing inhibitory activity against fouling bacteria suggests that sponge-associated bacteria could be potential sources of novel natural products.

Key words: marine sponge, Pseudoceratina purpurea, sponge associated bacteria, antibacterial activity, Bacillus, Virgibacillus

Marine sponges are known to produce a wide array of bioactive secondary metabolites. Sponges house archae, cyanobacteria and unicellular algae ${ }^{8)}$, many of which play supporting roles in nutrition ${ }^{29)}$, defense against predators and biofouling ${ }^{2,26)}$. Sponges are also known to maintain numerous bacteria which can amount to up to $40 \%$ of the biomass of a sponge ${ }^{28}$. It has been reported that the ratio of bacteria with antimicrobial activity isolated from marine invertebrates was higher than that from other sources ${ }^{3)}$. Bacteria associated with marine invertebrates might be a chemical defense for their host. Considering the cooperative relationships between bacterium and sponge in chemical defense, there is further potential to seek for natural products in bacteria associated with marine invertebrates.

The marine sponge Pseudoceratina purpurea (Order Verongida, Family Aplysinellidae) found in shallow waters in the Gulf of Mannar, India, is almost free of fouling or-

\footnotetext{
* Corresponding author; nagata@maritime.kobe-u.ac.jp, Tel: +8178-431-6342, Fax: +81-78-431-6364
}

ganisms and at the same time has proven to be a rich source of interesting metabolites. A number of sponge species, such as Psammopemma sp., Psammaplysilla purpurea, Aplysina aerophoba, and Dysidea herbacea, produce brominated aromatic metabolites, bromoindoles, bromophenols, polybrominated diphenyl ethers and di-bromodibenzo- $p$ dioxins $^{27)}$. Many sponge or sponge symbiont-derived metabolites are potent antibacterial, antifungal, antifeeding and antifouling compounds ${ }^{1)}$. Some marine bioproducts originally isolated from macroorganisms, such as sponges, have been subsequently discovered to be present in microbial associates ${ }^{2)}$. The role of sponge-associated microorganisms in the synthesis of compounds of biological interest is a subject of scientific debate, as in some cases these bacteria are reported to produce bioactive metabolites ${ }^{12)}$. The marine surface-associated bacterium Pseudoalteromonas tunicata strain D2 produces a number of extracellular inhibitors during the stationary phase of growth that affect the normal settlement and growth of a variety of common marine fouling organisms ${ }^{10)}$. The Vibrio spp. associated with the sponge 
Dysidea species were shown to synthesize cytotoxic and antibacterial tetrabromodiphenyl ethers ${ }^{5)}$. In addition, diketopiperazines produced by a Micrococcus species associated with the sponge Tedania ignis were found to have potent antimicrobial activity ${ }^{22)}$.

Many previous studies on antimicrobial activity have tested sponge metabolites against terrestrial or medically important strains in order to search for novel antimicrobial agents. But metabolites may affect ecologically relevant bacteria in a different manner. From an ecological point of view, it is also important to test sponge extracts and surface associated bacterial extracts against bacteria that sponges would naturally encounter in the environment. While there is abundant evidence that crude organic extracts of marine invertebrates exhibit antimicrobial activity against medically important bacteria, the susceptibility of ecologically relevant bacteria to such activity has rarely been studied ${ }^{8}$. Bacteria of the genus Vibrio are typically found in marine habitats where they are often attached to surfaces. Luminescent bacteria such as Photobacterium species are commonly used to test the effect of antifouling compounds ${ }^{30)}$. To test the inhibitory activities of sponge-associated bacteria we have selected a series of fouling bacteria isolated from a natural biofilm formed on antifouling paint-coated plates and a set of Vibrio and Photobacterium species. The aim of this study was to isolate bacteria with antimicrobial activities from the $P$. purpurea sponge and to identify potent bacterial strains using a $16 \mathrm{~S}$ rRNA phylogenetic analysis.

\section{Materials and methods}

\section{Sponge materials}

The marine sponge $P$. purpurea was collected from a depth of $5 \mathrm{~m}$ along the coastal waters of Mandapam, Gulf of Mannar $\left(09^{\circ} 16^{\circ} \mathrm{N}, 79^{\circ} 08^{\circ} \mathrm{E}\right)$, India and washed with sterile seawater to remove adhering debris and associated biota. Then the sponge was squeezed softly to eliminate most of the extraneous water and soaked in methanol before being transported to the laboratory. Final processing of the sponge was carried out by crushing it into smaller pieces and filtering through a fine mesh using $90 \%$ methanol by percolation 3 times at ambient temperature. These extracts were evaporated dry under reduced pressure. The concentrated methanol extracts were stored and used to check for antibacterial properties.

\section{Isolation of sponge-associated bacteria, preliminary screening, and preparation of bacterial supernatant}

Additional $P$. purpurea individuals were collected and rinsed thoroughly with sterile seawater to remove looselyattached bacteria before swabbing with a sterilized cotton swab from different portions of the sponge surface. The swab was then used to directly inoculate standard Marine agar medium (Himedia, Bombay, India) which contained (per liter) peptone $5 \mathrm{~g}$, yeast extract $1 \mathrm{~g}$, ferric citrate $0.1 \mathrm{~g}$, $\mathrm{K}_{2} \mathrm{HPO}_{4} 0.5 \mathrm{~g}$, and agar $15 \mathrm{~g}(\mathrm{pH} 7.5)$. Colonies with different morphologies on agar medium after incubation at $30^{\circ} \mathrm{C}$ were selected. Altogether, 102 strains were recovered from the sponge surface and stored for further screening.

For the preliminary screening, pure cultures of surfaceassociated bacteria were inoculated into $10-\mathrm{ml}$ aliquots of nutrient broth which contained (per liter) Bactopeptone (Difco Laboratories, Detroit, MI, USA) 5 g, yeast extract (Difco) $3 \mathrm{~g}, \mathrm{NaCl} 30 \mathrm{~g}, \mathrm{CaCl}_{2} \cdot 2 \mathrm{H}_{2} \mathrm{O} 0.1 \mathrm{~g}, \mathrm{MgSO}_{4} \cdot 7 \mathrm{H}_{2} \mathrm{O}$ $0.7 \mathrm{~g}, \mathrm{NH}_{4} \mathrm{Cl} 1.0 \mathrm{~g}, \mathrm{~K}_{2} \mathrm{HPO}_{4} 35 \mathrm{mg}$ and $\mathrm{KH}_{2} \mathrm{PO}_{4} 15 \mathrm{mg}(\mathrm{pH}$ 7.5). At an exponential phase of growth at $30^{\circ} \mathrm{C}$, each culture was centrifuged $\left(15,000 \times g, 4^{\circ} \mathrm{C}, 5 \mathrm{~min}\right)$. Antibacterial testing of the extracts which were concentrated from supernatants 10 fold was performed by the paper disc diffusion technique in agar plated Petri dishes as previously described $^{7)}$. A volume of $60 \mu \mathrm{l}$ of concentrated supernatant was then used to saturate a sterilized paper disc (Whatman, $6 \mathrm{~mm}$ ), allowed to dry at room temperature, and placed on the surface of Marine agar plates which had been freshly swabbed with the liquid cultures of Escherichia coli K-12 IFO 3301. Among 102 bacteria, 4 which were highly active against E. coli IFO 3301 were selected for further experiments.

To check their resistance to sponge metabolites, these four bacteria were spread over the Marine agar plates and the sponge crude extracts $(60 \mu \mathrm{l})$ were used to test their activity with the same paper disc diffusion assay. All four bacteria showed resistance to the sponge crude extracts (no inhibition zone) and these strains were designated PS2, PS9, PS11 and PS79. For further bioassay experiments, each of these strains was inoculated into $100 \mathrm{ml}$ of nutrient broth and incubated for $24 \mathrm{~h}$ at $30^{\circ} \mathrm{C}$. The supernatants were then collected and concentrated 10 fold.

\section{Isolation of fouling bacteria}

The fouling bacteria were isolated from an artificially developed biofilm on the surface of steel plates coated with zinc pyrithione and pyridine triphenylborane, two antifouling agents found in paint. The plates coated with the antifouling agents were left for 2 months in Osaka Bay $\left(34^{\circ} 43^{\circ} \mathrm{N}, 135^{\circ} 17^{\circ} \mathrm{E}\right)$, Japan. The thin biofilm that developed on the steel plate surface was washed with sterilized seawater, and a swab was used immediately to directly inoc- 
ulate plates of Marine agar medium. Based on differences in colony morphology and pigmentation we isolated 12 strains, designated FB-1, FB-2, FB-3, FB-4, FB-5, FB-6, FB-7, FB-8, FB-9, FB-10, FB-11 and FB-12 in this study.

\section{Vibrio and Photobacterium species}

As representative of marine bacteria, five species belonging to the genera Vibrio and Photobacterium were used in this study. These were $V$. harveyi IFO 15634, Photobacterium phosphoreum IFO 13896, P. damselae IFO 15633, V. fischeri DSM 7151, and V. alginolyticus 138-2 (from $\mathrm{H}$. Tokuda, The University of Tokyo) ${ }^{25)}$.

\section{Bioassay against growth of fouling bacteria and Vibrio species}

Sponge extracts and bacterial supernatant $(60 \mu \mathrm{l})$ loaded on each of the paper discs were allowed to dry at room temperature. Vibrio spp., Photobacterium spp. and the twelve fouling bacteria, FB-1 to FB-12, were grown in nutrient broth for $24 \mathrm{~h}$, at which point $0.1-\mathrm{ml}$ aliquots were spread over the agar medium. After incubation for $24 \mathrm{~h}$, antibacterial activity was evaluated by measuring the inhibition zone (in $\mathrm{mm}$ ) from the edge of the disc. Control tests with methanol alone were performed for every assay, but showed no inhibition.

\section{DNA extraction and PCR amplification}

Bacteria were grown in a modified LB medium ( $\mathrm{pH} 7.0)$ consisting of $5 \mathrm{~g} / \mathrm{l}$ dry yeast extract D-3 (Nihon Pharmaceuticals, Tokyo, Japan), $10 \mathrm{~g} / \mathrm{l}$ polypepton (Nihon Pharmaceuticals) and $2 \mathrm{~g} / \mathrm{l} \mathrm{NaCl}$. Bacterial pellets were collected from $1 \mathrm{ml}$ of culture by centrifugation $\left(18,000 \times g, 4^{\circ} \mathrm{C}\right)$ for $5 \mathrm{~min}$. These pellets were used for extracting genomic DNA which was achieved using a Blood and Tissue Genomic DNA Extraction Miniprep System (Viogene, Illkirch Cedex, France), following the manufacturer's instructions.

PCR amplification of the 16S rRNA gene was carried out using GeneAmp PCR System 9700 (Applied Biosystems, Foster City, CA, USA). The total reaction volume of $30 \mu \mathrm{l}$ included $3.0 \mu \mathrm{l}$ of $10 \times$ Taq Buffer with $\mathrm{MgCl}_{2}$ (Promega, Madison, Wisconsin, USA), $3.0 \mu$ of dNTP mixture (Takara-Bio, Shiga, Japan), 2.1 pmol of each primer, 0.8 units of Taq polymerase (Promega) and $1.0 \mu$ of DNA solution. The oligonucleotide primers used (27f;5'-GAGTTTGATCCTGGCTCA-3', 1385r;5'-CGGTGTGTRCAAGGCCC-3') were based on a previous report ${ }^{8)}$. The conditions for PCR were as follows; initial denaturation at $95^{\circ} \mathrm{C}$ for $5 \mathrm{~min}$; 30 cycles of denaturation at $95^{\circ} \mathrm{C}$ for $30 \mathrm{~s}$, annealing at $54^{\circ} \mathrm{C}$ for $30 \mathrm{~s}$, extension at $72^{\circ} \mathrm{C}$ for $30 \mathrm{~s}$; and a final extension at $72^{\circ} \mathrm{C}$ for
$7 \mathrm{~min}$. The PCR products were ligated into the pT7Blue Tvector (EMD Biosciences, San Diego, CA, USA). Plasmids were introduced into Escherichia coli strain JM109 by electroporation using a Micro Pulser (Bio-Rad Laboratories, Hercules, CA, USA). Plasmids were sequenced using the BigDye Terminator Cycle Sequencing Reaction Kit (Applied Biosystems) and ABI PRISM 377 Genetic Analyzer (Applied Biosystems).

\section{DNA sequencing and phylogenetic analysis}

The 16S rRNA gene sequences were compared with all other known rRNA gene sequences through a BLAST search (http://www.ddbj.nig.ac.jp/search/blast-j.html). Similar rDNA sequences were downloaded from the database and aligned with our sequences. The Clustal W program ${ }^{24)}$ was used for preliminary DNA sequence alignment, followed by a manual final alignment. The aligned sequences were subjected to maximum parsimony (MP) analyses in a general heuristic search using PAUP v. $4.0 \mathrm{~b}^{2} \mathrm{a}^{23)}$. Twenty random taxon addition replicates were performed in each heuristic search with the Goloboff fit criterion $(k=2)$, using the TBR branch-swapping option. Gaps were considered as missing data in the MP analysis. From the same alignment, two-parameter distances between taxa were estimated, and a phylogenetic tree was constructed with the neighbour-joining (NJ) method, using PAUP. The robustness of the resulting trees was tested by a bootstrap analysis ${ }^{6)}$ with 1000 resamplings.

\section{Nucleotide sequence accession numbers}

The 16S rRNA gene sequences have been deposited into the DNA Data Bank of Japan (DDBJ)/GenBank with the following accession numbers: PS2 (AB196350), PS9 (AB196351), PS11 (AB196352) and PS79 (AB196353).

\section{Results and Discussion}

\section{Primary screening of sponge isolates}

In our earlier study ${ }^{17)}$ we demonstrated that some surfaceassociated bacteria isolated from the marine sponge Psammaplysilla (=Pseudoceratina) purpurea have the ability to inhibit pathogenic bacteria. In the present investigation, four bacteria (PS2, PS9, PS11 and PS79) were selected after a screening based on their resistance to host metabolites and inhibition of strain IFO 3301. The sponge crude extracts were tested against these four bacterial cultures using the paper disc diffusion method, which indicated that none of the bacteria was inhibited by sponge extracts. The results of the primary screening based on their potential tolerance of 
host metabolites suggested that these four bacteria were not common free-living bacteria (planktonic) but instead associated with the surface of the host. Earlier reports stated that the production of secondary metabolites by marine organisms may serve to protect against colonization, and hence bacteria attaching to such surfaces are likely to resist host metabolites as well as to express phenotypes which will enable the cells to adhere to the surface ${ }^{11)}$. By analogy, bacteria that are resistant to the bioactive metabolites of their host might be capable of producing antimicrobial compounds themselves ${ }^{19)}$.

\section{Activity against fouling bacteria}

To characterize the antimicrofouling activity of the $P$. purpurea sponge isolates, bacterial supernatants were first tested against a set of fouling bacteria collected from a natural marine biofilm. To compare bacterial inhibitory activity, sponge crude extracts were also included in the bioassay. To ensure that the bacteria collected from the marine environment are actually fouling bacteria we have isolated 12 fouling bacteria from a natural biofilm formed on plates coated with antifouling paint. Their characteristics and partial identification are summarized in Table 1. Gram staining experiments revealed that the fouling bacteria FB-1, FB-4, FB-8 and FB-9 were Gram-positive, while the rest were Gramnegative. In the first test against fouling bacteria, the sponge extracts were active against all 12 fouling bacteria and the supernatants of sponge-associated bacteria inhibited only some of the fouling bacteria as shown in Table 2. The supernatant obtained from four bacteria had no activity against fouling bacteria such as FB-4, FB-5, FB-8, FB-9, and FB11, including three Gram positive and two Gram negative strains. Here, we define mild, moderate and strong activities as an inhibition zone of $<2 \mathrm{~mm}, 2-5 \mathrm{~mm}$ and $\gtrsim 5 \mathrm{~mm}$, respectively. Mild activity was found against FB-3, FB-10 and FB-12 (all Gram negative) and even this inhibitory effect differed from strain to strain, i.e. supernatant from strain PS11 had no effect against strain FB-3, but inhibited strains FB-10 and FB-12. Moderate activity was found against strains FB-1, FB-2 and FB-7, which include one Gram positive and two Gram negative strains. The greatest inhibition was found against strain FB-6 (Gram negative) where the zone produced by the supernatant of PS9 was larger than that of the sponge extract. The inhibitory effects of 4 isolates against strain FB-7 were also strong or almost equivalent to that of sponge extracts. At least one of the supernatants from sponge-associated bacteria was active against strains FB-1, FB-2, FB-3, FB-6, FB-7, FB-10 and FB-12 (Fig. 1). In general, all the bacterial supernatants were active mostly against Gram negative bacteria and only one Gram-positive bacterium (FB-1) was inhibited by any of the four bacterial compounds.

In screening for substances with antifouling activity, the paper disc diffusion assay employing fouling bacteria as the target organism has been widely used as an indicator of antifouling potential ${ }^{4}$. These four associated bacteria showing some specificity in their antimicrobial activity therefore may contain some metabolites which have the potential to inhibit the attachment of fouling microorganisms in natural environments.

\section{Activity against Vibrio and Photobacterium species}

In the second panel of the test, the sponge crude extracts were highly active against all the Vibrio species used in this

Table 1. Fundamental features of bacterial species isolated from marine natural biofilms formed on the surface of plates coated with antifouling paint

\begin{tabular}{|c|c|c|c|c|}
\hline Fouling bacteria & Gram & Color & Shape & Elevation \\
\hline FB-1 & + & yellow & cocci & convex \\
\hline FB-2 & - & pale orange & rods & convex \\
\hline FB-3 & - & fluorescent & short rods & flat \\
\hline FB-4 & + & white & cocci & convex \\
\hline FB-5 & - & white & rods & convex \\
\hline FB-6 & - & yellowish cream & rods & raised \\
\hline FB-7 & - & pale yellow & short rods & flat \\
\hline FB-8 & + & ivory & rods & convex \\
\hline FB-9 & + & white & cocci & convex \\
\hline FB-10 & - & pale white & rods & convex \\
\hline FB-11 & - & colorless, transparent & rods & flat \\
\hline FB-12 & - & pale white & filamentous & raised \\
\hline
\end{tabular}


Table 2. Antimicrofouling activities* of supernatants from sponge-associated bacteria and sponge extract from Pseudoceratina purpurea

\begin{tabular}{clllll}
\hline \multirow{2}{*}{ Fouling Bacteria } & \multicolumn{4}{c}{ Supernatants of sponge-associated bacteria } & \multirow{2}{*}{ Sponge extract } \\
\cline { 2 - 5 } & PS2 & PS9 & PS11 & PS79 & 6.5 \\
FB-1 & 3 & 6 & 1.5 & 6 & 7 \\
FB-2 & 4.5 & 4 & 5 & 0.5 & 8 \\
FB-3 & 0.5 & 0.5 & 0 & 0 & 9 \\
FB-4 & 0 & 0 & 0 & 0 & 2 \\
FB-5 & 0 & 0 & 0 & 0 & 9 \\
FB-6 & 0 & 10 & 5 & 6 & 7 \\
FB-7 & 5 & 0 & 0 & 0 & 8 \\
FB-8 & 0 & 0 & 0.5 & 0 & 7 \\
FB-9 & 0 & 0 & 0 & 0 & 5 \\
FB-10 & 0 & 0 & 0.5 & 0 & 4 \\
FB-11 & 0 & 0.5 & 0 & 0 \\
\hline
\end{tabular}

* Antimicrofouling activity was determined as a zone of inhibition (in $\mathrm{mm}$ ) measured from the edge of the disc after $24 \mathrm{~h}$ of incubation; $0=$ no activity.
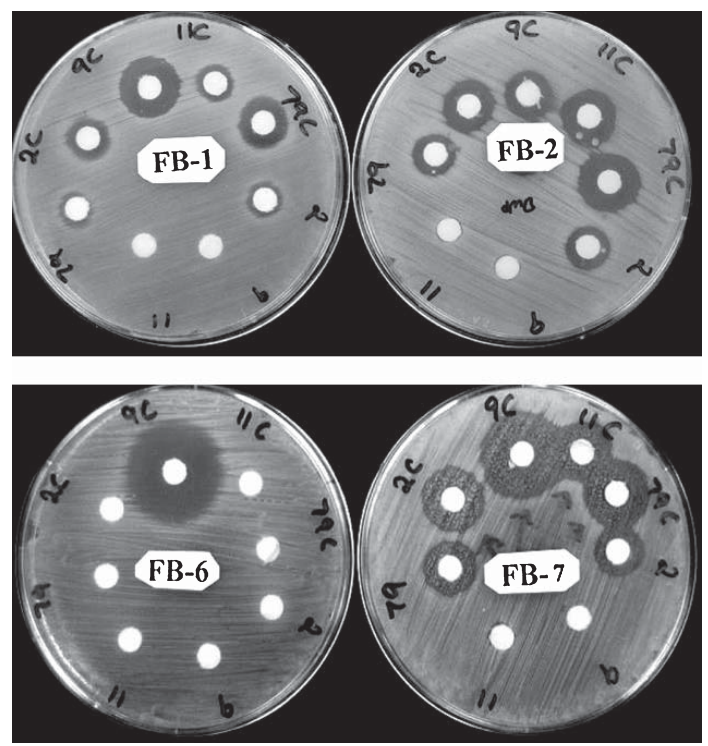

Fig. 1. Supernatant activity of sponge surface-associated bacteria against fouling bacteria FB-1, FB-2, FB-6 and FB-7. Fouling bacteria were collected from the biofilm formed on plates coated with antifouling paint. $2 \mathrm{C}, 9 \mathrm{C}, 11 \mathrm{C}$ and $79 \mathrm{C}$ indicate $60 \mu \mathrm{l}$ of $10-$ fold concentrated bacterial supernatant from strains PS2, PS9, PS11 and PS79 that were isolated from the marine sponge P. purpurea, respectively.

study (Table 3). The supernatants of four sponge-associated bacteria were not active against the strain $V$. harveyi. Moderate and high levels of activity were recognized against $V$. fischeri and $V$. alginolyticus, respectively. The supernatant of the isolate PS79 was almost as active against $V$. algi- nolyticus as the sponge extracts. An earlier study indicated that a strain of Vibrio isolated from a marine biofilm promotes the settlement of spores ${ }^{20)}$. In addition, marine Vibrio species were found to be a major cause of bleaching in corals through effects on the coral's symbiotic zooxanthellae ${ }^{15)}$.

Sponge extracts inhibited the growth of both Photobacterium species but none of the bacterial supernatants was active against them (Table 3). Both of these luminous bacteria were reported to contribute to the microfouling community in the marine environment. In addition, Photobacterium species have been widely used in assessing the toxicity of antifouling compounds. The antibacterial effect of the supernatant was species specific, i.e., it inhibited the growth of only some fouling bacteria as well as two Vibrio species but did not inhibit Photobacterium species.

In this study, the production of compounds by bacteria on the surfaces of marine sponge suggests that there are some interactions taking place between the sponge and bacteria and these associated bacteria may play a role in the defensive mechanisms of the host. Such interactions are not uncommon in the marine environment with epibiotic bacterial species implicated in the production of toxic metabolites originally attributed to their host $\mathrm{t}^{26}$.

Thus, it seems plausible that some surface-associated bacteria have adapted to defend their position on the sponge surface through the production of bioactive metabolites which are active against other bacteria. In this study it has been demonstrated that bacteria which are associated with the sponge $P$. purpurea are capable of affecting the surface ecosystem through the production of (chemical) metabo- 
Table 3. Activities of supernatants from sponge-associated bacteria and sponge extract from Pseudoceratina purpurea against Vibrio and Photobacterium species*

\begin{tabular}{lccccc}
\hline \multirow{2}{*}{ Fouling strains } & \multicolumn{3}{c}{ Supernatants of sponge-associated bacteria } & \multirow{2}{*}{ Sponge extract } \\
\cline { 2 - 5 } & PS2 & PS9 & PS11 & PS79 & 13 \\
\hline Vibrio alginolyticus 138-2 & 8 & 5 & 4 & 12 & 6.5 \\
Vibrio harveyi IFO 15634 & 0 & 0 & 0 & 0 & 11 \\
Vibrio fischeri DSM 7151 & 3 & 4 & 0 & 2.5 & 4.5 \\
Photobacterium damselae IFO 15633 & 0 & 0 & 0 & 0 & 9 \\
Photobacterium phosphoreum IFO 13896 & 0 & 0 & 0 & 0 & 9 \\
\hline
\end{tabular}

* Antibacterial activity was determined as a zone of inhibition (in $\mathrm{mm}$ ) measured from the edge of the disc after $24 \mathrm{~h}$ of incubation; $0=$ no activity.

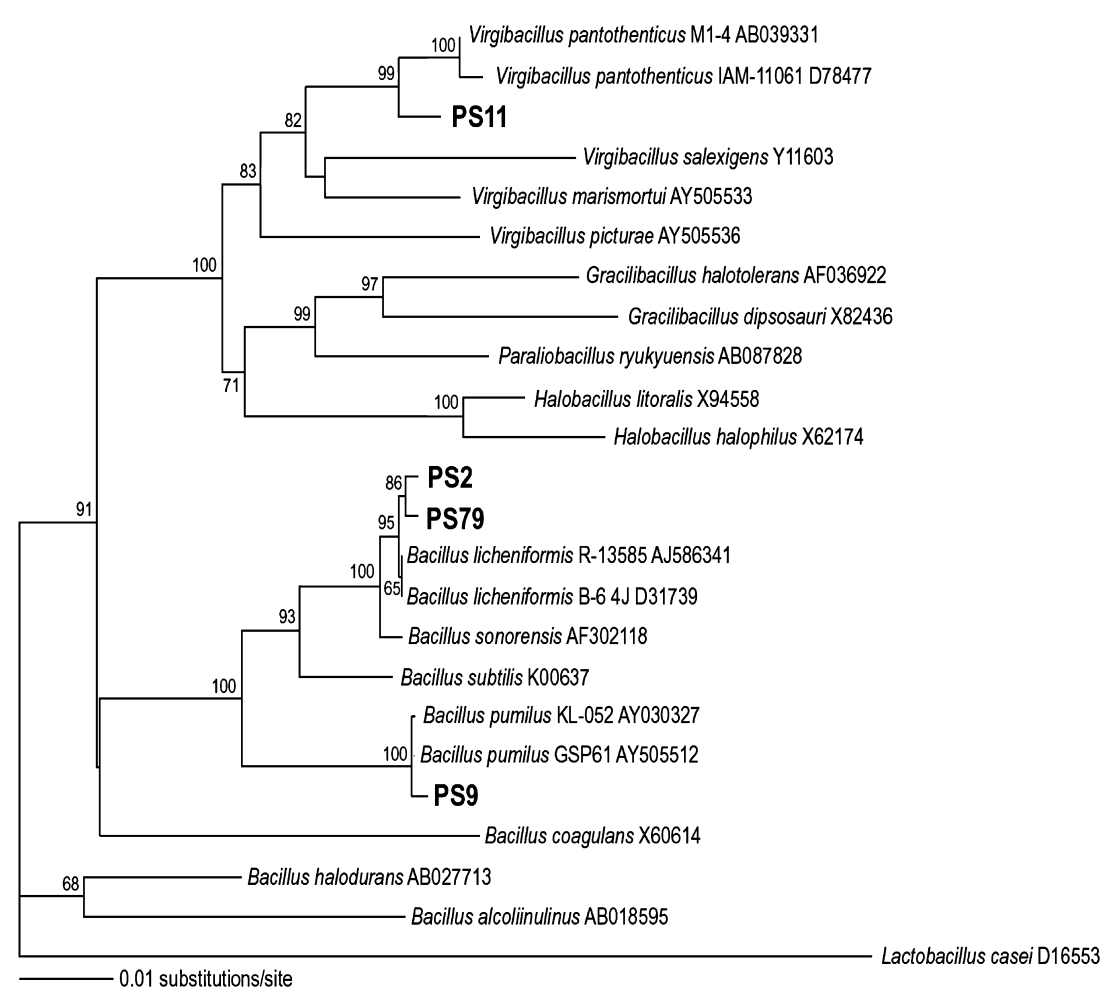

Fig. 2. Neighbor-joining analysis of 16S rRNA gene sequences from several species of Bacillaceae and strains PS2, PS9, PS11 and PS79 isolated from the marine sponge $P$. purpurea. The scale bar indicates $1 \%$ sequence divergence. Numbers at nodes represent bootstrap values in percentage terms based on 1000 replicates.

lites. The sponge seems to have selective control of the bacterial epibiosis on its surface. This relation may help the sponge in governing epibacterial populations on its surface by deterring settlement of other microbes.

\section{Phylogenetic characterization of isolates}

For phylogenetic characterization, the 16S rRNA gene sequences of 24 species were compared with the GenBank database using the BLAST programme, including 4 newly reported sequences. The aligned sequences comprised a to- tal of 1399 sites and contained 214 parsimony-informative nucleotide positions. In the MP analysis, one maximum parsimonious ( 770 steps, $\mathrm{CI}=0.6078, \mathrm{RI}=0.7127)$ tree was found. Tree topologies were essentially the same for maximum parsimony and neighbour-joining analyses (Fig. 2). Molecular phylogenetic analysis showed that all bacterial isolates belong to the family Bacillaceae. Neighbor-joining analysis of 16S rRNA gene sequences revealed that the isolates PS2 and PS79 belong to Bacillus licheniformis. In addition, the isolates PS9 and PS11 belong to Bacillus pumilus 
and Virgibacillus pantothenticus, respectively. There is 99.7\% similarity (4 bp difference) between PS2 and PS79, and both isolates showed greater than $99.7 \%$ similarity to Bacillus licheniformis. The isolate PS9 showed greater than 99.7\% similarity to Bacillus pumilus. The isolate PS11 showed $98.9 \%$ sequence similarity to Virgibacillus pantothenticus.

Bioactive metabolites have been reported in a variety of Bacillus species ${ }^{16)}$, rendering this genus one of the most active producers of bioactive metabolites. Even though Bacilli are reported to be terrestrial bacteria, they have been isolated from marine coastal and open ocean environments on multiple occasions ${ }^{13)}$. Bacilli have also been isolated from marine sponges, such as Ircinia felis ${ }^{21)}$, Aplysina aerophoba ${ }^{8)}$, and soft corals. Furthermore, Bacillus species are well known producers of metabolites with antimicrobial, antifungal, or generally cytotoxic properties ${ }^{31}$. Surfactin possessing a dipeptide moiety was initially isolated from a marine sponge, and thereafter it was shown that the bacterium, Bacillus pumilus, which is associated with the sponge, is the real producer of these compounds ${ }^{14)}$. Also B. pumilus has been reported to produce lipopeptides, such as pumilaci$\operatorname{din} \mathrm{A}$ and $\mathrm{B}$, which contain antiviral activity ${ }^{18)}$. As with most other Bacillus species, marine Bacillus species are able to produce peptide compounds with antimicrobial activity $^{8)}$.

Among the numerous Bacillus species, only B. badius, $B$. subtilis, B. cereus, B. licheniformis, B. firmus, B. pumilus, $B$. mycoides, and $B$. lentus were reported to be detected in marine environments ${ }^{13}$. The genus Virgibacillus was recently created with $V$. pantothenticus, formerly known as $B$. pantothenticus as the type species ${ }^{9)}$. This is the first time that Virgibacillus pantothenticus has been isolated from a marine sponge, as far as we know.

In conclusion, this study demonstrated that four surfaceassociated bacteria from $P$. purpurea suppressed fouling bacteria isolated from natural biofilms and inhibited the growth of two Vibrio species. Based on the present findings, it is envisaged that the bioassay-guided purification and fractionation of these bacterial metabolites will provide leads for the development of environmentally-friendly antifouling compounds.

\section{Acknowledgements}

We thank Prof. Toshihide Tamura, Hyogo College of Medicine, for his generous help and valuable suggestions. We also wish to thank Mr. Zhou Xiaojian, Kobe University, for his help in collecting fouling bacteria.

\section{References}

1) Becerro, M.A., M.J. Uriz and X. Turon. 1997. Chemically mediated interactions in benthic organisms: the chemical ecology of Crambe crambe (Porifera Poecilosclerida). Hydrobiologia 355 : 77-89.

2) Bewley, C.A., N.D. Holland and D.J. Faulkner. 1996. Two classes of metabolites from Theonella swinhoei are localized in distinct populations of bacterial symbionts. Experientia 52: 716722.

3) Burgess, J.G., E.M. Jordan, M. Bregu, A. Mearns-Spragg and K.G. Boyd. 1999. Microbial antagonism: a neglected avenue of natural products research. J. Biotechnol. 70: 27-32.

4) Clare, A.S. 1996. Marine natural product antifoulants: status and potential. Biofouling 9: 211-229.

5) Elyakov, G.B., T. Kuznetsova, V.V. Mikhailov, I.I. Maltsev, V.G. Bionov and S.A. Fedoreyev. 1991. Brominated diphenyl ethers from a marine bacterium associated with the sponge Dysidea sp. Experientia 47: 632-633.

6) Felsenstein, J. 1985. Confidence limits on phylogenies: an approach using bootstrap. Evolution 39: 783-791.

7) Hellio, C., D. De La Broise, L. Dufosse, Y. Le Gal and N. Bourgougnon. 2001. Inhibition of marine bacteria by extracts of macroalgae: potential use for environmentally friendly antifouling paints. Mar. Environ. Res. 52: 231-247.

8) Hentschel, U., M. Schmid, M. Wagner, L. Fieseler, C. Gernert and J. Hacker. 2001. Isolation and phylogenetic analysis of bacteria with antimicrobial activities from the Mediterranean sponges Aplysina aerophoba and Aplysina cavernicola. FEMS Microbiol. Ecol. 35: 305-312.

9) Heyndrickx, M., L. Lebbe, K. Kersters, P. De Vos, G. Forsyth and N.A. Logan. 1998. Virgibacillus: a new genus to accommodate Bacillus pantothenticus (Proom and Knight 1950). Emended description of Virgibacillus pantothenticus. Int. J. Syst. Bacteriol. 48: 99-106.

10) Holmstrom, C., S. James, B. Neilan, D. White and S. Kjelleberg. 1998. Pseudoalteromonas tunicata sp. nov., a bacterium that produces antifouling agents. Int. J. Syst. Bacteriol. 48: 1205-1212.

11) Holmstrom, C., S. Egan, A. Franks, S. McCloy and S. Kjelleberg. 2002. Antifouling activities expressed by marine surface associated Pseudoalteromonas species. FEMS Microbiol. Ecol. 41: 4758.

12) Imhoff, J.F. and R. Stöhr. 2003. Sponge-associated bacteria: general overview and special aspects of bacteria associated with Halichondria panicea, pp. 35-56. In W.E.G. Müller (ed.), Marine Molecular Biotechnology. Springer-Verlag, Berlin.

13) Ivanova, E.P., M. Vysotskii, V. Svetashev, O. Nedashkovskaya, N. Gorshkoval, V. Michailov, N. Yumoto, Y. Shigeri, T. Taguchi and S. Yoshikawa. 1999. Characterization of Bacillus strains of marine origin. Int. Microbiol. 2: 267-271.

14) Kalinovskaya, N., T. Kuznetsova, Y. Rashkes, Y. Milgrom, E. Milgrom, R. Willis, A. Wood, H. Kurtz, C. Carabedian, P. Murphy and G. Elyakov. 1995. Surfactin-like structures of five cyclic depsipeptides from the marine isolate of Bacillus pumilus. Russ. Chem. Bull. (English translation) 44: 951-955.

15) Kushmaro, A., E. Rosenberg, M. Fine and Y. Loya. 1996. Bleaching of the coral Oculina patagonica by Vibrio AK-1. Mar. Ecol. Prog. Ser. 147: 159-165.

16) Lebbadi, M., A. Galvez, M. Maqueda, M. Martinez-Bueno and E. Valdivia. 1994. Fungicin M4: a narrow spectrum peptide antibi- 
otic from Bacillus licheniformis M-4. J. Appl. Bacteriol. 77: 4953.

17) Manmadhan, K., K. Nagata, Y. Fujita, T. Tamura, H. Okamura and S. Nagata. 2004. Antibacterial activity of marine sponge Psammaplysilla purpurea: Importance of its surface associated bacteria. Proceedings of Oceans'04 MTS/IEEE TechnoOcean'04 Conference, Kobe, Japan, pp. 1323-1329.

18) Naruse, N., O. Tenmyo, S. Kobaru, H. Kamei, T. Miyaki, M. Konishi and T. Oki. 1990. Pumilacidin, a complex of new antiviral antibiotics: production, isolation, chemical properties, structure and biological activity. J. Antibiot. (Tokyo) 43: 267-280.

19) Pabel, C., J. Vater, C. Wilde, P. Franke, J. Hofemeister, B. Adler, G. Bringmann, J. Hacker and U. Hentschel. 2003. Antimicrobial activities and matrix-assisted laser desorption/ionization mass spectrometry of Bacillus isolates from the marine sponge Aplysina aerophoba. Mar. Biotechnol. 5: 424-434.

20) Patel, P., M.E. Callow, I. Joint and J.A. Callow. 2003. Specificity in the settlement-modifying response of bacterial biofilms towards zoospores of the marine alga Enteromorpha. Environ. Microbiol. 5: 338-349.

21) Prokofeva, N.G., N.I. Kalinovskaya, P.A. Lukyanov, E.B. Shentsova and T.A. Kuznetsova. 1999. The membranotropic activity of cyclic acyldepsipeptides from bacterium Bacillus pumilus, associated with the marine sponge Ircinia sp. Toxicon 37: 801-813.

22) Stierle, A.C., J.H. Cardellina II and F.L. Singleton. 1988. A marine Micrococcus produces metabolites ascribed to the sponge Tedania ignis. Experientia 44: 1021.

23) Swofford, D.L. 1999. PAUP*: Phylogenetic analysis using parsimony (*and other methods), Version 4.03ba. Sinauer Associates, Sunderland, Massachusetts.

24) Thompson, J.D., D.G. Higgins and T.J. Gibson. 1994. CLUSTAL
W-improving the sensitivity of progressive multiple sequence alignment through sequence weighting, position specific gap penalties and weight matrix choice. Nucleic Acids Res. 22: 46734680.

25) Unemoto, T., T. Tsuruoka and M. Hayashi. 1973. Roles of $\mathrm{Na}^{+}$ and $\mathrm{K}^{+}$in preventing lysis of slightly halophilic Vibrio alginolyticus. Can. J. Microbiol. 19: 563-571.

26) Unson, M.D., N.D. Holland and D.J. Faulkner. 1994. A brominated secondary metabolite synthesized by the cyanobacterial symbiont of a marine sponge and accumulation of the crystalline metabolite in the sponge tissue. Mar. Biol. 119: 1-11.

27) Utkina, N.K., V.A. Denisenko, O.V. Scholokova, M.V. Virovaya, A.V. Gerasimenko, D.Y. Popov, V.B. Krasokhin and A.M. Popov. 2001. Spongiadioxins A and B, two new polybrominated dibenzo-p-dioxins from an Australian marine sponge Dysidea dendyi. J. Nat. Prod. 64: 151-153.

28) Vacelet, J. and C. Donadey. 1977. Electron microscope study of the association between some sponges and bacteria. J. Exp. Mar. Ecol. 30: 301-314.

29) Wilkinson, C.R. and R. Garrone. 1980. Nutrition of marine sponges. Involvement of symbiotic bacteria in the uptake of dissolved carbon, pp. 157-161. In D.C. Smith and Y. Tiffon (ed.), Nutrition in the Lower Metazoa, Pergamon, Oxford.

30) Zhou, X.J., H. Okamura and S. Nagata. 2004. Bioluminescence assay of antifoulants and seawater samples using Vibrio fischeri cells, pp. 63-69. In The $6^{\text {th }}$ Asia-Pacific Marine Biotechnology Conference, Zhoushan, P. R. China.

31) Zuber, P., M.M. Nakano and M.A. Marahiel. 1993. Peptide antibiotics, pp. 897-916. In A.L. Soneshein, J.A. Hoch and R. Losick (ed.), Bacillus subtilis and other Gram-positive bacteria. American Society for Microbiology, Washington, D.C. 